\title{
A Study on the Factors Affecting Reading and Reading Habits of Preschool Children
}

\author{
Bunyamin Celik ${ }^{1}$ \\ ${ }^{1}$ Department of Languages, Tishk International University, Erbil, Iraq \\ Correspondence: Bunyamin Celik, Department of Languages, Tishk International University, Erbil, Iraq. E-mail: \\ bunyamin.celik@ishik.edu.iq
}

Received: October 16, 2019 Accepted: November 14, 2019 Online Published: December 15, 2019

doi:10.5539/ijel.v10n1p101 URL: https://doi.org/10.5539/ijel.v10n1p101

\begin{abstract}
In the developing world, reading habit, which is one of the first habits of traditional education, continues primarily in the family and then in kindergartens. In this research, factors such as family, environment, kindergarten and libraries are discussed in terms of acquiring reading habit in preschool period and evaluations are made about the effects of these factors on reading habit. In this study, the results of the research on the factors in the reading habit of Ishık Kindergarten students of Ronaki Hawler Education Company in Erbil, Iraq are included. Within the scope of the research, one-on-one interviews were conducted with 106 children in the six-year age group who were closest to starting primary school among the kindergarten students and 20 kindergarten teachers and a questionnaire was conducted. In this process, the kindergarten was observed. Then, the data obtained from the questionnaires were analyzed in SPSS program. In addition, structured interviews provided information about activities that aimed at acquiring reading habits of kindergarten teachers. In the conclusion part of the study, the data obtained were evaluated in terms of the factors that enable children to acquire reading habits. The results of the study showed that families have a guiding role in having the children acquire the reading habit. In addition, it was concluded that the group of friends, the environment, various books and genres, kindergarten education and libraries were other important elements in this preparation period.
\end{abstract}

Keywords: reading habit, preschool children, kindergarten, library

\section{Introduction}

Iraq is a center where many societies have a different cultural, sociological and political structure and have shed light on science in the past. In a center where such differences exist together, the importance of education, especially pre-school education, is appreciated. According to many valuable studies conducted in the world, it is a fact that education taken at a young age is necessary and useful in terms of personality formation and acquiring positive habits. In the so-called preschool period, which covers the years between birth and primary school age, children who are developing rapidly in social and spiritual terms besides basic skills are also able to learn quickly and easily. For this reason, it is important to pass this period with a conscious and attentive education (Glascoe, Altemeier, \& MacLean, 1989; Dwyer, Higgs, Hardy, \& Baur, 2008).

In this context, reading skill is one of the most important factors in self-improvement and adaptation to life. Reading is considered one of the basic building blocks of the whole learning process. One can learn through vision and hearing, but reading is one of the main ways of acquiring knowledge. Bacon said "Reading makes a full man, conference a ready man, and writing an exact man." (Lewis, 2014). Reading is the field of learning that makes the greatest contribution to mind development. In the process of reading, sentences are translated into mental concepts, structured in the brain and the reader makes sense of these sentences (Sun, 2007). Through what $\mathrm{s} / \mathrm{he}$ reads, people understand the developments around them, and thanks to what $\mathrm{s} / \mathrm{he}$ read, $\mathrm{s} / \mathrm{he}$ direct their behavior towards the events people encounter in daily life.

However, reading is not one of the innate characteristics of man. Although this feature is fully acquired in primary school age, it is seen that people are prepared to read by various factors in preschool period. Preschool children are not expected to be individuals who have acquired reading habits because children are illiterate. However, preschool period is very important for laying the foundations of reading habit. Studies in the field of education have shown that the learning experiences of preschool children are influenced by children's experiences as well as developmental factors. During this period, play and entertainment are at the forefront. In 
addition, the effects of the environment they live on children's development have been confirmed by these studies (Roskos \& Neuman, 2017; Neuman, 1999; Smith \& Dickinson, 1994).

Successful communication in all areas of life positively affects both the social and psychological aspects of the individual. Therefore, the environment in which children are present and his/her communication with the people around them are very important for mental development. In this sense, the development of children is in the form of playing while learning by following the people around them. During this period, children's interactions with the book take place through their curiosity and discovery. This interaction, which begins with picture books, continues with books containing short texts between the pictures in a way that prepares the child to learn to read slowly and in this process, the child is constantly interacted with the book. As a result of each interaction with the book, the child acquires new knowledge and his interest in reading increases. For this reason, it is important to ensure that the child interacts with the books in the pre-school period and that the child is interested in the books. As a matter of fact, according to Wilkinson (1988), the preparatory period when the child gets to know the school is generally provided by the education given in kindergartens.

There are many studies on reading habits at various levels such as primary and university level. Studies on preschool children have mostly focused on children's books and the impact of books on child development. More specialized research conducted by educators appears to be related to children's readiness to read and write, libraries and the impact of libraries on reading habits or general reading development.

In addition, it is very common to see in the literature that the studies are handled from the perspective of children's literature and children's books. In this context the interest of children towards books, picture books and reading and writing skills of preschool children are investigated (Üstün, 2007; Murray \& Bowden, 2006; Jackman, 2005; Brabham \& Korkeamaki, 1998; Hudson \& Fivush, 1991).

In the studies related to the readiness of preschool children, the issue was mostly handled by educators and studies were conducted on the subject of family, educational environments and teachers (Bracken \& Fischel, 2008; Watson, 2004; Wise \& Buffington, 2004; Sevinç, 2003).

Another important factor in reading and acquiring habits is the introduction of pre-school children to libraries. Moreover, library services for children are of great importance in this field (Yılmaz, 2009; Y1lmaz, 2008; Hills, 2005). In another aspect, considering the economic and sociological dimensions of the developing world, children's departments of public libraries are an important alternative for such environments, which are equipped with well-educated personnel and accessible to everyone and free of charge. The services to be provided in these places are crucial for creating a lifelong love of reading and a society that carries this desire.

In this study, the preschool period which forms the basis for the transformation of reading and reading action into a habit and the factors that affect the readiness of the child to read are discussed. The main purpose of this study is to determine the factors that affect the readiness of the child and the preschool period which forms the basis of the conversion of reading and reading action into a habit. In the study, a case study was conducted in Ishık Kindergarten within the Ronaki Hawler Education Company in Erbil, Iraq, to determine what activities are taken into account the level of readiness of children and the factors that are effective in acquiring reading habits. In addition, general information is given about reading habits and the factors that provide reading habits of preschool children and the findings of the research and the results obtained are presented.

\section{Reading, Reading Habits and the Period of Preschool}

Reading is one of the most important steps in understanding and learning. As it includes other language skills, education through reading is more important and intensive studies are carried out in this field. Reading is an action that enables the formation of human behaviors, self-improvement and gaining a world view (Demirel, 2000).

According to Dökmen (1994, p. 15), "Reading does not mean seeing words or sentences; In order to be able to read, especially to understand and read, a number of mental activities beyond seeing are required." Therefore, reading the emotions, thoughts and dreams in our mind can be described as coded by writing, this written message is perceived by the recipient by means of visual organs and can be described as matching with their counterparts in our mind (Fountas, Pinnell, \& Le Verrier, 2001).

Reading is a behavior that develops over time and gained through education rather than habit. Reading is the visual follow-up of a written text, according to some, and its perception with the brain. According to some others, it is a process which consists of a combination of different factors that require special education. Reading is not a habit that can be gained by compulsion, on the contrary it should be understood as a basic necessity and it is seen to be continuous, especially when paid attention from an early age. 
This period, which covers the period between the ages of two and six years of people, is included in the literature as early childhood period. While preschool children experience the most lasting learning activity, children develop rapidly in various areas such as cognitive, mental and as well as language (Anthony, Lonigan, Burgess, Driscoll, \& Phillips, 2002; Storch \& Whitehurst, 2002; Lonigan, Burgess, \& Anthony, 2000).

The acquisition of reading habits to the society and the individuals who make up the society is of great importance in terms of social development. According to Bracken and Fischel (2008), as in other habits, the most appropriate period in the formation of reading habits is childhood. In addition, encountering and writing materials in preschool period is a beginning for the formation of reading habits.

The first reading skills are manifested by the child's interest in written materials around him, recognition of logos and signs, recognition of the spelling of his name, and recognition of some letters in the alphabet (Flook, Goldberg, Pinger, \& Davidson, 2015; Üstün, 2007). During this period, the child starts to gain reading skills gradually and prepares for the school period in which he will be trained to have reading skills.

\section{Factors Affecting Reading Habits Among Preschool Children}

It is possible to talk about the various factors that affect the child's reading habits. These elements can be explained in general as education given in family, environment and preschool education institutions. These elements are also directly influential in the formation of the child's personality (Flook, Goldberg, Pinger, \& Davidson, 2015; Glascoe, Altemeier, \& MacLean, 1989).

\subsection{Family Factor}

In early childhood, the most important factor in the development of children is the family. The place where the child's educational process begins is the family environment and the first educators' children encounter are their parents (Wise \& Buffington, 2004). From the moment the child is born, the child develops with the support of his/her parents, and this development is not solely the fulfillment of the physical needs necessary for survival. In the preschool period, children learn by seeing everything around them, and the decisive model for children is their parents. Regarding the environment in which children will acquire reading skills, Storch and Whitehurst (2002) stated that the first environment in which children will acquire reading skills is the home environment, and that the first interaction with these skills is established with parents, siblings. In general, it is possible to say that for preschool children, parents are the main source of information in learning the environment and elements in life. Therefore, the special time spent by parents with their children in preschool period affects their attitudes towards literacy. In these years, parents have the opportunity to equip their children with positive experiences against reading. Thanks to this opportunity, families can ensure that their children develop a positive attitude towards the book and approach the book with confidence. Parents' support of the literacy and storytelling experiences of preschool children reinforces the development of these skills (Üstün, 2007; Watson, 2004; Pellegrini, Brody, \& Sigel, 1985). In home environments, the selection of reading materials by parents to appeal to children's interests, ideas and hobbies, making the material being read understandable for them and sharing the pleasure of reading together support children's literacy skills. For example, books that are read to the child by the mother and father benefit from many aspects such as developing the imagination and vocabulary development of the child (National Network for Child Care, 2002). Research has shown that children who come from a family environment with rich reading materials (newspapers, books, etc.), who work with drawing and completion books to improve visual and auditory perception, who participate in reading activities with large picture books, who are told stories and fairy tales develop their skills faster. Children who have acquired literacy skills in the pre-school period can understand that the lines move from left to right and written materials can be read and reading materials can also be put into written format, so s/he associates written language and spoken language with their own experiences (Çelenk, 2003; Pellegrini, Brody, \& Sigel, 1985).

In addition to this, an important factor to be mentioned is that according to many researches in this field, families in the lower and middle income groups have similar goals for their children, but families show great differences in supporting the education of their children because of their opportunities (Celano \& Neumann, 2001). In this case, some children were found to be inadequate in reading habit acquisition due to lack of equal economic and educational opportunities (Bracken \& Fischel, 2008; Keles, 2006; Klebanov, 1998).

For example, it was found that families with low socio-economic and cultural levels interacted less verbally with their children, and consequently, vocabulary development was low in children. As the vocabulary knowledge is related to literacy skills, it is found that the children of families who give less verbal interaction opportunity to their children have low literacy skills. On the other hand, it has been found that families with high socio-economic and cultural levels and who spend specially allocated time with their children have high language and literacy skills (Constantine, 2004). 
Another important activity that parents need to do is to provide children with books and magazines that are appropriate for the child's level (Üstün, 2007; Korkeamaki, 1998; Hudson \& Fivush, 1991). Thus, children spend more time with books and magazines. Preschool children's literature has been developed as a branch of children's literature for preschool children and a lot of research has been done to determine which kind of books children prefer according to their age groups. According to this, the children at the beginning of the preschool period mostly try to understand the picture-centered texts and follow the story from the picture and expect them to read it from their parents (Hudson \& Fivush, 1991). In the development of the child, this situation increasingly leads to an interest in text rather than pictures. Throughout this process, children establish connection between painting and text and understand the story from pictures.

Although the conditions and life standards of the parents are different, adults who serve as guide for children, as much as possible, go through visual sources together with the child and reach the answers to the questions together, increasing the general cultural knowledge of the child and increasing their interest in literacy. In this case, the child realizes that he/she has to develop his/her reading and writing skills in order to reach new information at an early age.

\subsection{Environmental Factor}

From the moment children are born, children develop according to what children see around them and live in an order that depends on the conditions of the environment. Another important factor that affects children's reading habits in preschool period is their environment. It is possible for the child to learn the world by questioning what he sees around him, and moreover, the environment in which children are present, and their communication with the people around them are very important for their mental and socio-cultural development. In this case, having children in such urging environment and giving them the opportunity to communicate securely with people is critical to their learning in these times (Bredekamp \& Copple, 1997).

Provided that children often encounter written materials in their environment, children begin to make a connection between spoken language and written language, even if children do not know how to read. Posters, pictures, books, letters, signs, newspapers, and other written materials with inscriptions on them allow children to discover that the written language corresponds to the verbal language and that it occurs through reading (Jenkins \& Eliason, 2008). At this point, the existence of a library in the child's room is effective in the formation of the child's reading environment. In studies conducted for children with a reading environment, it was stated that children who have a bookcase in their homes or in their rooms are more likely to comprehend and be more successful than other children (Sangkaeo, 1999).

\subsection{Pre-School Educational Institutions as a Factor}

Preschool education institutions are generally children's libraries, kindergartens where the child will spend the most time after the family (Jenkins \& Eliason, 2008; Brabham, Murray, \& Bowden, 2006). One of the most important factors in the acquisition of reading skills for children is preschool education institutions and the quality of education provided in these institutions. In addition to this, the need for pre-school education institutions increased in the modern world due to the increase in awareness about the importance of pre-school education, the transition of families from large family structure to nuclear family structure, the increase in the number of working parents and child-centered families, and thus, the expectations about the education systems of pre-school education institutions increased. In this way, children attending these institutions have different experiences, gain experiences and as a result of this, s/he becomes aware of many facts about his/her environment and the world. This awareness makes children more sensitive to their environment and increases their interest in discovering.

The education given in preschool education institutions is generally between the ages of 3 and 6 years. The educational role provided by the parents in this age group passes to the teachers in the kindergarten. Children at the end of preschool age of 5 and 6 are mostly in need of trust, love and learning (Jackman, Beaver, \& Wyatt, 2014). Making arrangements to meet these needs in preschool education institutions is very important in terms of the development of children in general and the skills for reading habits especially when s/he takes into consideration that almost all the needs of the child were met by the family in the period before the educational institution. Providing a comfortable environment to meet the needs of the child during this transition period will also contribute to the child's adaptation and success in the future. In addition, teacher's attitudes towards reading and guidance are important while preparing the child to gain reading habits. It is important and necessary for the teachers to be knowledgeable about children's literature, to have the ability to choose qualified books, to make the book attractive for the child, to plan the story-telling hours that are not boring. This kind of activities develop and nourish the child and are full of surprises and also serve to sow the seeds of reading pleasure and habit in the 
child.

One of the most important factors contributing to the preparation of the child in reading and preparing for school is the role of the educator in preschool education institutions. In this period, the educator replaces the parents so as to form a model. It guides the development of the child's personality (Brabham, Murray, \& Bowden, 2006). Children do not only encounter a teacher and a different environment in preschool education institutions, but children also make friends. The environment acquired during this period has an important role in the child's reading habits and personality development. In addition, during preschool period, children need to read the books that other children around them read. This is due to the fact that the child thinks that there will be a lack of interest in him among his friends if he does not read a book that his friends read. Influenced by friends, the child can change reading into a habit easily later (Claessens, Duncan, \& Engel, 2009; Broström, 2002). In preschool education, the kind of education given in kindergarten has the greatest effect on the preparation of the child for school and readiness to perform the reading action. The environment and the quality of education provided to children in kindergartens are extremely important for children to acquire reading habits.

\subsubsection{Libraries}

Libraries that have an impact on children's reading habits and are located in preschool education institutions also have a special role in children's reading habits. Taking children to children's libraries at regular intervals allows them to interact more with materials that will enable them to acquire reading habits. On the other hand, activities organized in children's libraries towards reading habits are effective in children's reading habits. In this sense, the existence of schools, public and children's libraries in the vicinity of the living environment or in pre-school institutions come to the forefront.

In addition to children's libraries, public libraries that are open to all and provide services for this purpose can also play an active role in children's reading habits. Kindergartens, day nurseries and kindergartens are known as early childhood institutions and their services are generally paid. Costs are difficult to cover for many families with low economic conditions. At this point, the most important candidates for such environments, which are equipped with rich material and trained personnel, are public libraries which are accessible to everyone and provide free services (Watson, 2004).

In addition, providing children with a library or a mini library in their own home will be a useful practice in terms of preparing for reading habits. Increasing the number and type of books in the home, the frequency of going to the library and the enjoyment of reading activities contribute much to gaining reading habit. Moreover, the connecting the content of the books with real life experiences also increases the tendency towards reading at home (Üstün, 2007). According to a study by Teale in 1999, libraries can work together to create programs that families can use at home and in the library to help their children acquire reading skills and habits (Teale, 1999). In addition to reading habits, it can be ensured that children acquire the habit of using library. In this respect, the fact that the libraries act together with the families in having preschool children acquire the reading habit will provide a guiding function both for raising the awareness of families about reading habits and for children to acquire reading habits.

\section{Methodology}

Within the scope of this research, 106 out of 143 children in the six-year age group who are in the last year of this education in preschool education in Ish1k Kindergarten were surveyed about activities to acquire reading habits. The sample consisted of children who were at school at the time of the study and were willing to answer the questionnaire. If any student does not volunteer to answer the questionnaire during the survey, this student's questionnaire was not taken into consideration. The representative power of the sample was $74.2 \%$. Within the scope of the questionnaire, besides the questions related to the education given in kindergarten, the factors that affect children's reading habits were also taken into consideration. The questionnaires were filled with one-to-one interviews with each child in private areas allocated by Ishık Kindergarten authorities to ensure that children were not affected by their friends' responses. The data obtained from the questionnaires were analyzed in SPSS program.

In addition, in order to evaluate the applicability of the questionnaire and to determine the appropriateness of the questions to the children's level, pre-test was applied on 10 children who were suitable for the characteristics of the children. As a result of this test, impressions were noted down about how the children perceived the questions and how children would be reflected to the children. In addition, two experienced teachers working at Ishık Kindergarten and kindergarten PDR experts gave positive opinions in the evaluation of the pre-test results.

In order to determine the factors affecting reading and reading habits of preschool children, answers to the 
following questions were sought.

- What is the frequency of parents' reading books to preschool children?

- What is the financial status and educational level of the families of the preschool children participating in the study?

- How do parents encourage their preschool child to read and what kind of reading activities do they do together?

- What are the main environmental factors in acquiring reading and reading habits for preschool children?

- What is the effect of preschool in terms of in-class or out of class activities in kindergarten on reading and reading habits?

- What is the effect of libraries on the reading and reading habits of preschool students?

In this descriptive study, structured interview technique was used to provide information about the effects of Ishık Kindergarten teachers on students and the activities teachers organized for students to acquire reading habits. The impressions about the environmental factors provided for the children to acquire reading habits in kindergarten were also taken into consideration and evaluated within the scope of the research.

\section{Findings and Discussion}

Qualitative and quantitative findings were obtained as a result of the method applied in the research. In the evaluation of the findings, the readiness levels of the children and the factors that affect the reading habits were taken into consideration. In this context, the impact of the families, the environment and the preschool education institution were evaluated separately.

\subsection{Family Factor}

In Ishık Kindergarten, a survey was conducted with children in the age group of six to obtain quantitative findings about the behaviors of families to encourage children to read.

Regarding the effect of families on children's reading habits, it was measured that the parents read books or other material to make the children interested in reading and whether this was observed by the children. According to the results in Table 1, the majority of the children (78\%) observed their parents while reading books and other materials.

Table 1. Frequency of parents' reading books to children

\begin{tabular}{lll}
\hline Frequency of Parents' Reading Books to Children & Number & $\%$ \\
\hline Every Day & 24 & 22.7 \\
Several times in a week & 31 & 29.2 \\
Less than twice a month & 33 & 31.1 \\
Never read & 18 & 16.9 \\
Total & 106 & 100 \\
\hline
\end{tabular}

In Table 1, the frequency of parents' reading books to the children is given. According to this, it is seen that families read books to their children several times a week (29.2\%), while the rate of families who regularly read books to their children is approximately one quarter (22.7\%) of the whole. This shows that one in four families reads to their children every day. In general, if s/he interprets the situation of reading books to children, half of the families (51.9\%) in the study read books to their children at least a few times a week.

When s/he looks at the family factor, it is observed that the socio-cultural environment in which the Middle East and Iraq are located and the economic situation of the families also affect the results. According to the information received from the school administration, families generally have a higher education level than most Iraqi cities. In addition, according to Table 2 (77.3\%), Ishık Kindergarten student families in Erbil where the study was conducted have a high financial status.

Table 2. Financial status of families

\begin{tabular}{lll}
\hline Financial Status of Families & Number & $\%$ \\
\hline Monthly income of \$ 5000 and above & 38 & 35.8 \\
Monthly income between \$ 3000 and \$ 5000 & 44 & 41.5 \\
Monthly income between \$ 1000 and \$ 3000 & 24 & 22.6 \\
Total & 106 & 100 \\
\hline
\end{tabular}


In Table 2, the monthly financial situation of the families is prepared by the information provided by the administration of Ishik Kindergarten. According to this, $35.8 \%$ of the families have a monthly income of $\$ 5000$ and over, $41.5 \%$ have a monthly income of $\$ 3000$ to $\$ 5000,22.6 \%$ have a monthly income of $\$ 1000$ to $\$ 3000$. According to the information given, it is observed that families generally do not have a financial problem.

In addition, according to Table 3, it was observed that the majority of the families $(80.2 \%)$ had a basic education level and that despite the low level of Undergraduate or Graduate (19.8\%), half of the parents $(51.9 \%)$ paid attention to reading and reading habits.

Table 3. Educational levels of families

\begin{tabular}{lll}
\hline Educational Levels of Families & Number & $\%$ \\
\hline Undergraduate \& Graduate & 21 & 19.8 \\
High School & 28 & 26.4 \\
Primary \& Secondary Education & 53 & 50 \\
Illiterate & 4 & 3.7 \\
Total & 106 & 100 \\
\hline
\end{tabular}

Table 3 is also based on the information provided by the administration of Ishik Kindergarten. Accordingly, it was found that $19.8 \%$ of the families were at the Undergraduate \& Graduate level, $26.4 \%$ at the High School and $50 \%$ at the Primary \& Secondary Education level, and $3.7 \%$ of the families were illiterate.

Reading and reading activities carried out by families with children are another factor that is effective for children to acquire reading habits. The questions in Table 4 below were asked to the students in this context. First of all, it was understood that the majority of the families (74.6\%) did not take their children to book fairs and did not act to ensure that children interact with the books. On the other hand, more than half of the families $(67 \%)$ took their children to bookstores and enabled children to interact with books in these settings.

The majority of the students (74.6\%) purchased a book during their visit to book fairs or bookstores, and almost all (91.5\%) bought a children's magazine. According to these results, children were more interested in children's magazines than the books and their families supported it. In addition, during the research, some children stated that "... I bought the book myself" and "I collected my own pocket money and bought the children's magazine". In the process of the purchase of the book, it was understood that the families gave the money directly to their children to make the payment, and encouraged the child to use the pocket money for other useful things and thus tried to arouse the feeling of ownership in the children.

One of the behaviors that will help the families to give more value to their children and help them gain reading habits is that families give their children books or children's magazines as a gift. Almost all of the children (92.4\%) who participated in the study were given books or children's magazines as a gift by their parents.

Table 4. Activities of families with children for reading and reading habits

\begin{tabular}{lll}
\hline Questions/activity & Yes/\% & No/\% \\
\hline Have you ever visited a book fair with your parents? & $22 / 25.4$ & $79 / 74.6$ \\
Have you ever visited a bookstore with your parents? & $71 / 67$ & $35 / 33$ \\
Have you ever bought any books on these visits? & $82 / 77.4$ & $24 / 22.6$ \\
Have you ever bought a children's magazine on these visits? & $97 / 91.5$ & $9 / 8.5$ \\
Have your parents ever given you books or magazines as a gift? & $98 / 92.4$ & $8 / 7.6$ \\
Total & $106 / 100$ & $106 / 100$ \\
\hline
\end{tabular}

According to these results, by taking into consideration the social and political situation of Iraq in general, their economic status and educational level, it was seen that the families who participated in the study had behaviors that would enable their children to value books more and to change their reading habits in a positive way.

\subsection{Environmental Factor}

Another factor that affects children's reading habits in preschool period is the environment in which children are born and raised. From the moment kids are born, children develop according to what children see around them and live in an order that depends on the conditions of the environment. The environment in which children live is usually provided by the family. In addition, the presence of books and other reading materials around the child 
creates the desire to read. The first signs of children's interest in reading occur as a result of interaction with the environment and observation of the environment. As a result of the child's interaction with the environment, the behaviors such as examining the elements containing a written text, recognizing the logos, recognizing the spelling of their name can be given as an example (Üstün, 2007; Roskos \& Neuman, 2001). In the study, some questions were asked to the children in order to investigate the environmental impacts and this was stated in Table 5.

Table 5. Environmental factors

\begin{tabular}{lll}
\hline Questions/activity & Yes/\% & No/\% \\
\hline Do you have one or more bookcases in your home or room? & $103 / 98$ & $3 / 2$ \\
Do you know the logo in the picture? (Fast Food Company) & $105 / 99$ & $1 / 1$ \\
Do you know the logo in the picture? (Automotive Company) & $104 / 98$ & $2 / 2$ \\
Do you know the logo in the picture? (Ishik Kindergarten Logo) & $106 / 100$ & $0 / 0$ \\
Do you know where your school's name is written? & $94 / 89$ & $12 / 11$ \\
Total & $106 / 100$ & $106 / 100$ \\
\hline
\end{tabular}

First of all, it is possible for the child to learn the world by questioning what he sees around him. At this point, the existence of a library in the child's room is effective in the formation of the child's reading environment. In studies conducted for children with a reading environment, it is stated that children who have a library in their homes or rooms are more likely to comprehend and succeed in reading compared to other children (Sangkaeo, 1999). Almost all of the students (98\%) who participated in the survey stated that there was a library in their room or home. This encourages both students and their families to read in a positive way.

In addition, analyses of children's interaction with reading-oriented elements in various environments such as the external environment and television were also conducted. Analyses related to environmental factors are mostly related to measuring children's awareness about reading elements in the environment. In this sense, the children were shown some logos and written materials that children saw in their environment or on television, and whether the children were aware of these elements was measured. First, the logo of a famous Fast Food Company was shown and 105 children (99\%) out of 106 recognized the logo and gave its name. Then, the logo of a famous car brand was shown and 104 children (98\%) out of 106 recognized the logo and gave its name. Finally, the kindergarten logo, which the children were educated, was shown to the children and all the children recognized the logo and gave its name. The findings revealed that all of the children (99\%) in the study were aware of the logos and materials containing the text. In the same way, the children were asked a question about where the name of the school was written and whether the children noticed the written materials around them. Accordingly, 94 out of 106 children (89\%) knew where the name of the school was written. Based on the questions asked, it can be said that almost all of the six-year-old children in the children's kindergarten have noticed many different written elements in their environment.

\subsection{Pre-School Educational Institutions as a Driving Factor}

\subsubsection{Educational Institutions-Kindergarten}

The education and conditions provided in educational institutions, where children spend the most time after their families in preschool period, have a direct effect on the child's reading habit. In this study, findings were obtained through structured interviews applied to the kindergarten teachers and administrators and observations.

As observed in Ishık Kindergarten during the research, Figures 1 and 2 clearly show that an intensive reading environment is created in the environment provided to children. 


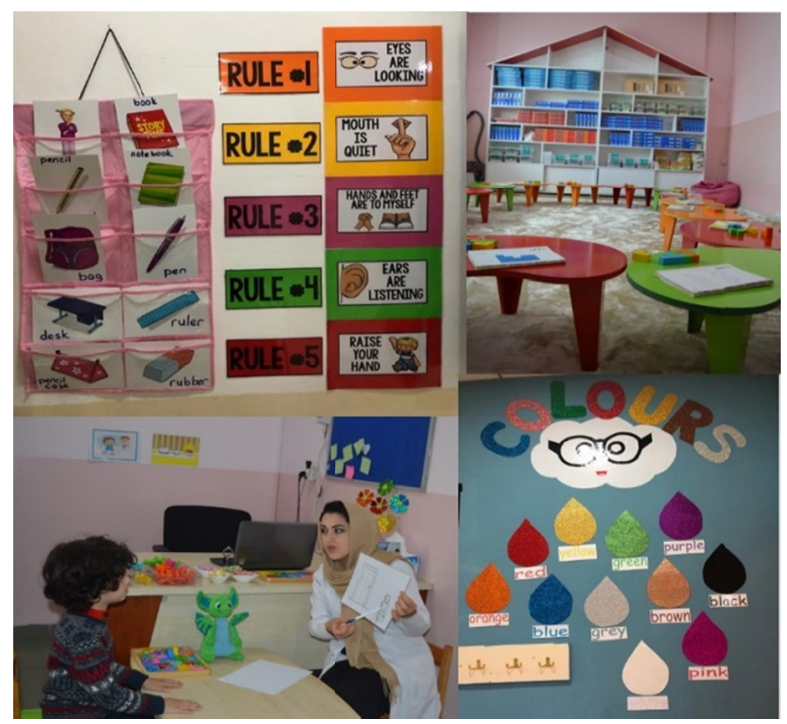

Figure 1. Intensive reading environment

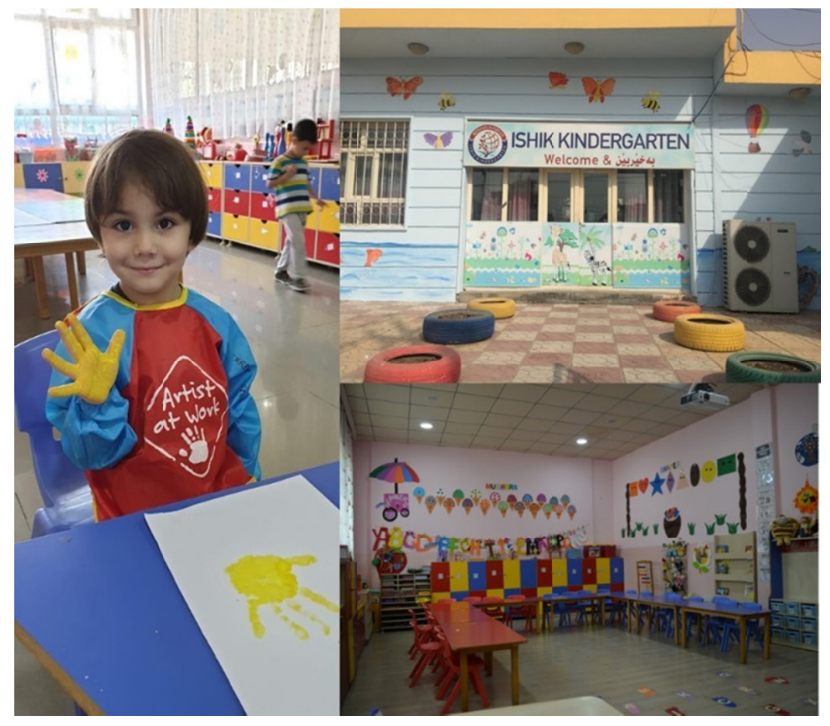

Figure 2. Intensive reading environment

With the numbers on the stairs, the arrangements in the classrooms and the libraries, the letters on the floor and the games played on these letters help children to acquire reading skills and studies are done to turn these skills into habit.

As an example of the studies, especially during the period of Nawruz, which is the harbinger of spring in March and the national holiday of Iraq, the theme named "Reading in Nawruz is Exclusively Fine" was determined by the kindergarten administration and this theme was supported with activities prepared by kindergarten teachers.

The following activities were organized in this period:

What/Why do we read?

"Reading and Listening Books and what we understood" Time.

What is a book made of?

Where are the books printed?

What to read outside the book? 
Let's Repair Books.

Let's Make Our Own Book.

Let's make our own magazine.

Let's make our own newspaper.

Let's Save and Buy Books / Magazines.

Let's Use the Class Library.

At the end of this month, both children and teachers were asked questions about activities in Table 6a and Table $6 \mathrm{~b}$ to find out the effects of the activities.

Table 6a. In-school activity—student thoughts

\begin{tabular}{lll}
\hline Questions- in-school activities & Yes/\% & No/\% \\
\hline Did you like the events in the Nawruz period? & $105 / 99$ & $1 / 1$ \\
Did you learn new things from Nawruz activities? & $95 / 89.7$ & $11 / 10.3$ \\
Did you create your own book? & $87 / 82$ & $19 / 18$ \\
Did you create your own magazine? & $97 / 91.5$ & $9 / 8.5$ \\
Did you create your own newspaper? & $82 / 77.3$ & $24 / 22.7$ \\
Did you take your products home and share them with your family? & $96 / 90.5$ & $10 / 9.5$ \\
\hline
\end{tabular}

In general, looking at the answers given to the questions of the children participating in the research in Table 6a, it was found that the activities were highly welcomed by the children and that kids could acquire reading and reading habits from the activities in the kindergarten.

Table 6b. In-school activity-tutorial considerations

\begin{tabular}{lll}
\hline Questions-in-school activities & Yes/\% & No/\% \\
\hline Did you like the events in the Nawruz period? & $20 / 100$ & $0 / 0$ \\
Do you think the children learned new things from Nawruz activities? & $20 / 100$ & $0 / 0$ \\
Do you find the activities of children creating them own book, magazines and newspapers positive? & $20 / 100$ & $0 / 0$ \\
Do you get positive feedback from the families about the activities? & $20 / 100$ & $0 / 0$ \\
Do you get any negative feedback? & $0 / 0$ & $20 / 100$ \\
Do you think similar in-school activities positively affect children's reading habits? & $20 / 100$ & $0 / 0$ \\
Total & $20 / 100$ & $20 / 100$ \\
\hline
\end{tabular}

In Table 6b, it was determined that 20 teachers who participated in classroom and school activities together with children answered all questions positively related to activities. As it can be seen clearly in Tables 6a and 6b, it was determined that all in-class and out-of-class activities carried out within the Kindergarten to gain the habit of reading books had motivating and positive effects on the students.

In addition, as a result of the interview with 20 teachers working in Ishık Kindergarten, some information was obtained about the environment and activities provided for children in kindergarten. In Ishık Kindergarten, it is stated that teachers organize reading activities at least once a day in order for children to acquire reading habits, and these activities include studies such as story book review, reading from the picture, and listening to stories.

In addition, it was stated by the teachers that there are magazines, encyclopedias and books for informing children about daily life in kindergarten environment.

The teachers stated that the school program supports reading activities as much as possible and that children think kids have the best interest in reading and books. In order to provide this interest, it was stated by the teachers that various activities such as drama, story-drawing and story-making were carried out with the children in the activities.

\subsubsection{Libraries}

Activities arranged in accordance with educational institutions should be supported with trips to the school library together with children. As can be seen in Table $7 \mathrm{~b}$, all of the 106 children who participated in the research went to the libraries according to the schedule implemented by the kindergarten and participated in the activities implemented together with the class. 
In addition, families should take their children to children's departments of public libraries in order to gain the habit of reading books. However, only 27 (25.4\%) of the 106 students who attended the questionnaire went to the library with their families before the kindergarten, and more than half $(63.3 \%)$ of the students went to the library on their own or together with their friends. 12 children $(11.3 \%)$ stated that children never went to the library until children started kindergarten.

Table 7a. Preschool children habits to go to the library

\begin{tabular}{ll}
\hline Their status to go to libraries & Number/\% \\
\hline With their friends or on their own & $67 / 63.3$ \\
Together with their families & $27 / 25.4$ \\
Never & $12 / 11.3$ \\
Total & $106 / 100$ \\
\hline
\end{tabular}

Table 7b. Preschool children habits to go to the library after children start kindergarten

\begin{tabular}{lll}
\hline Their status to go to libraries & Yes, I went/\% & No, never went $/ \%$ \\
\hline With other children & $106 / 100$ & none \\
Total & $106 / 100$ & $106 / 100$ \\
\hline
\end{tabular}

These results reveal that the factors that affect children's use of libraries are school and friends rather than families.

\section{Conclusion and Discussion}

It has been shown that the preschool period, which includes many critical periods that children spend until the beginning of primary education, includes the critical years especially for the development of early academic skills of children. The information learned in this period directly affects the development of children in later periods. With the rapid progression of cognitive development in preschool period, academic skills also progress depending on cognitive development. The development of children especially for the acquisition of reading skills in this period is also effective in their interest in reading in the following periods and turning this behavior into a habit by gaining continuity. In our study, the readiness of the preschool children attending the kindergarten only for reading habits has been examined and considering the realities of the social, political, cultural and economic situation in Iraq, it is known that there is a considerable proportion of children who cannot go to kindergarten. It is a potential research subject to examine the pre-school children who are not preschool children, especially in cities and centers that are smaller than Erbil, affected by poverty and political problems, both in terms of preparation for reading habits and supporting children's libraries. In addition, there are also differences in the opportunities offered by kindergartens serving preschool children in this region. In this respect, it is known that kindergartens carry out the most appropriate reading activities for children in accordance with the opportunities children have. In Ishık Kindergarten examined in our study, it is seen that activities that are different and exemplary in terms of reading activities are observed.

In this study, the factors that affect the reading habit of Ishık Kindergarten students in preschool period were investigated. In the context of the researched factors, the effect of the families was taken into consideration. The most important factor in children's reading habits is their families. Parents play a key role in children's reading habits, as well as many other issues.

At the end of the study, the findings of the study showed that families engaged in various activities such as reading books, buying books and telling fairy tales for their children to gain reading habits and thus, families enabled children to become interested in reading and acted as motivators for their children to gain reading habits in the future. As a result of the research, in addition to the positive characteristics related to the effect of families, it was observed that families were inadequate in some subjects. The most important of these is going to the library and book fairs with the children. However, the rate of families going to bookstores with their children is quite high.

Another factor that was dealt with in the study and which was effective in acquiring children's reading habit is the effect of the environment. It is seen that the majority of children in the research have a wide reading environment. In addition to their families, a group of friends is also effective in creating a reading environment for children in preschool period.

Children in this period are directly affected by the behaviors of their friends. For this reason, the group of friends 
formed in the preschool education institution is effective in creating the willingness of the child in the activities organized in the school. In addition, the friendship environment positively affects the formation of the child's reading environment by enabling interaction with institutions such as library. In order to spread the love of the book to the general public, the role of institutions such as public libraries in which people from all walks of life and from all age groups can easily access should be increased and such institutions should be structured to attract public attention. In other words, in order to use public libraries, physical and technological infrastructures must be capable of responding to daily needs, and personnel and service quality should be sufficient.

In this sense, it was observed that children used the library mostly together with their friends and teachers. When the environment provided for children in Ishık Kindergarten is examined, it is seen that children are provided with an intensive reading environment and this environment is used effectively with the organized activities.

Considering the facilities in Iraq and according to the research, Ishık Kindergarten is an example for other schools in terms of the activities organized in preschool institutions. In Ishık Kindergarten, observations and interviews with the authorities showed that children were familiar with books and other reading materials, how books were printed, and how the library was used. Teachers play the most important role in organizing such activities. Teachers' awareness of reading and reading habits directly affects the development of children. In Ishik Kindergarten, both teachers' opinions and observations during the research show that teachers are quite aware of this issue.

\subsection{Recommendations}

In the light of the results obtained from the study, it is possible to make some recommendations for the elements that are effective in acquiring reading skills for preschool children by taking Ishık Kindergarten example into consideration.

- Public and children's libraries should play an active role in eliminating the inadequacies of the families especially in the activities such as going to book fairs and libraries with their children. Kindergartens can also warn families.

- Awareness raising can be provided by institutions working together to prepare special education programs for families about the development of preschool children and helping them to gain reading habits.

- The promotion of the programs prepared by libraries for preschool children will also have a significant impact on the awareness of families. Similar cooperation between institutions should be made between public and children libraries and preschool institutions.

- It is important for the students of pre-school teaching departments of the universities to do their internship in public and children's libraries, and it will be beneficial to have departmental courses in their curriculum like habit of reading and using the library. Regular visits to kindergarten students and public-children libraries will also benefit.

- Considering that kindergartens are the place where the most time is spent after the family environment for preschool children, the necessary arrangements are to be made and the authorities should be made conscious of this.

- In the establishment of kindergartens, arrangements should be made for children to spend time without bored, to move freely and to a rich reading environment with a separate library in each classroom as well as a school library should be created.

- In addition to the environment provided to children and the family, the presence of teachers with sufficient knowledge of reading habits, frequent organizing of reading activities and increasing the interaction of children with reading materials in preschool education institutions will be effective in helping children to acquire reading habits in the future.

\section{References}

Anthony, J. L., Lonigan, C. J., Burgess, S. R., Driscoll, K., Phillips, B. M., \& Cantor, B. G. (2002). Structure of preschool phonological sensitivity: Overlapping sensitivity to rhyme, words, syllables, and phonemes. Journal of Experimental Child Psychology, 82(1), 65-92. https://doi.org/10.1006/jecp.2002.2677

Brabham, E. G., Murray, B. A., \& Bowden, S. H. (2006). Reading alphabet books in kindergarten: Effects of instructional emphasis and media practice. Journal of Research in Childhood Education, 20(3), 219-234. https://doi.org/10.1080/02568540609594563

Bracken, S. S., \& Fischel, J. E. (2008). Family reading behavior and early literacy skills in preschool children 
from low-income backgrounds. Early Education and Development, 19(1), $45-67$. https://doi.org/10.1080/10409280701838835

Bredekamp, S., \& Copple, C. (1997). Developmentally appropriate practice in early childhood programs. Washington, D.C.: National Association for the Education of Young Children. ERIC Number: ED403023.

Broström, S. (2002). Communication and continuity in the transition from kindergarten to school. In Transitions in the early years (pp. 76-87). Routledge.

Çelenk, S. (2003). İlkokuma-Yazma Öğretiminde Kuluçka Dönemi. Ankara Üniversitesi Ĕ̆itim Bilimleri Fakültesi Dergisi, 36(1), 75-80. https://doi.org/10.1501/Egifak_0000000073

Claessens, A., Duncan, G., \& Engel, M. (2009). Kindergarten skills and fifth-grade achievement: Evidence from the ECLS-K. Economics of Education Review, 28(4), 415-427. https://doi.org/10.1016/j.econedurev.2008.09.003

Constantine J. L. (2004). Relationships among early lexical and literacy skills and language-literacy environments at home and school. Unpublished $\mathrm{PhD}$ thesis, College of Education University of South Florida, Department of Childhood Education College of Education University of South Florida, USA. Retrieved from https://scholarcommons.usf.edu/etd/1000

Demirel, Ö. (2000). Türkçe Öğretimi. Ankara: Pegem A Yayıncılık.

Dökmen, Ü. (1994). Okuma Becerisi, Ilgisi ve alışkanlığı Üzerine Psiko-Sosyal Bir Araştırma. İstanbul: Milli Eğitim Bakanlığg Yayınları.

Dwyer, G. M., Higgs, J., Hardy, L. L., \& Baur, L. A. (2008). What do parents and preschool staff tell us about young children's physical activity: a qualitative study. International Journal of Behavioral Nutrition and Physical Activity, 5(1), 66. https://doi.org/10.1186/1479-5868-5-66

Flook, L., Goldberg, S. B., Pinger, L., \& Davidson, R. J. (2015). Promoting prosocial behavior and self-regulatory skills in preschool children through a mindfulness-based kindness curriculum. Developmental Psychology, 51(1), 44-51. https://doi.org/10.1037/a0038256

Fountas, I. C., Pinnell, G. S., \& Le Verrier, R. (2001). Guided reading. Portsmouth. NH: Heinemann. https://doi.org/10.4324/9780203155158

Glascoe, F. P., Altemeier, W. A., \& MacLean, W. E. (1989). The importance of parents' concerns about their child's development. American Journal of Diseases of Children, 143(8), 955-958. https://doi.org/10.1001/archpedi.1989.02150200115029

Güneş, F. (2007). Türkçe ögrretimi ve zihinsel yapılandırma. Nobel Yayın Dağıtım.

Hills, V. (2005). Preschool preparation: the importance of an early academic foundation. The Free Library Articles and Books, 18, 2008.

Hudson, J. A., \& Fivush, R. (1991). As time goes by: Sixth graders remember a kindergarten experience. Applied Cognitive Psychology, 5(4), 347-360. https://doi.org/10.1002/acp.2350050405

Jackman, H., Beaver, N., \& Wyatt, S. (2014). Early education curriculum: A child's connection to the world. Cengage Learning.

Jackman, L. H. (2005). Early Education Curriculum: A Child's Connection to the World (3rd ed.). Thomson Delmar Learning, NY.

Jenkins, L. T., \& Eliason, C. (2008). A practical guide to early childhood curriculum. Pearson Merrill/Prentice Hall.

Keleş, Ö. (2006). İlköğretim 4. ve 5. sınıf öğrencilerinde kitap okuma alışkanlı̆̆ının incelenmesi. Yayınlanmamış Yüksek Lisans Tezi. Gazi Üniversitesi, Eğitim Bilimleri Enstitüsü.

Klebanov, P. K., Brooks - Gunn, J., McCarton, C., \& McCormick, M. C. (1998). The contribution of neighborhood and family income to developmental test scores over the first three years of life. Child Development, 69(5), 1420-1436. https://doi.org/10.1111/j.1467-8624.1998.tb06221.x

Korkeamaki, R. L. (1998). How first graders and kindergarten children constructed literacy knowledge in the context of story reading and meaningful writing.

Lewis, R. (2014). Francis Bacon and Ingenuity. Renaissance Quarterly, 67(1), $113-163$. https://doi.org/10.1086/676154 
Lonigan, C. J., Burgess, S. R., \& Anthony, J. L. (2000). Development of emergent literacy and early reading skills in preschool children: evidence from a latent-variable longitudinal study. Developmental Psychology, 36(5), 596. https://doi.org/10.1037//0012-1649.36.5.596

Neuman, S. B. (1999). Books make a difference: A study of access to literacy. Reading Research Quarterly, 34(3), 286-311. https://doi.org/10.1598/RRQ.34.3.3

NICHD Early Child Care Research Network. (2002). Early child care and children's development prior to school entry: Results from the NICHD Study of Early Child Care. American Educational Research Journal, 39(1), 133-164. https://doi.org/10.3102/00028312039001133

Pellegrini, A. D., Brody, G. H., \& Sigel, I. E. (1985). Parents' book-reading habits with their children. Journal of Educational Psychology, 77(3), 332-340. https://doi.org/10.1037/0022-0663.77.3.332

Roskos, K., \& Neuman, S. B. (2001). Environment and its influences for early literacy teaching and learning. Handbook of Early Literacy Research, 1, 281-294.

Sangkaeo, S. (1999). Reading Habit Promotion in ASEAN Libraries. ERIC Number: ED441496

Sevinç, M. (2003). Okul öncesi dönemde okuma yazma kavramlarının gelişimi. M. Sevinç.

Smith, M. W., \& Dickinson, D. K. (1994). Describing oral language opportunities and environments in Head Start and other preschool classrooms. Early Childhood Research Quarterly, 9(3/4), 345-366. https://doi.org/10.1016/0885-2006(94)90014-0

Storch, S. A., \& Whitehurst, G. J. (2002). Oral language and code-related precursors to reading: Evidence from a longitudinal structural model. Developmental Psychology, 38(6), 934-947. https://doi.org/10.1037/0012-1649.38.6.934

Teale, W. H. (1999). Libraries Promote Early Literacy Learning: Ideas from Current Research and Early Childhood Programs. Journal of Youth Services in Libraries, 12(3), 9-16. ERIC Number: EJ591582

Üstün, E. (2007). Okul öncesi çocuklarının okuma yazma becerilerinin gelişimi. İstanbul: Morpa Kültür.

Watson, J. S. (2004). Family literacy: Support for young readers and their parents. School Library Media Activities, 20(8), 24-48. ERIC Number: EJ784598

Wilkinson, L. C. (1988). Chapter 5: Grouping Children for Learning: Implications for Kindergarten Education. Review of Research in Education, 15(1), 203-223. https://doi.org/10.3102/0091732X015001203

Wise, J., \& Buffington, S. (2004). The ordinary parent's guide to teaching reading. Peace Hill Press.

Yılmaz, A. (2008). Okulöncesi çocuklara yönelik kütüphane hizmetlerinin önemi ve başarılı bir kütüphane örneği. Türk kütüphaneciliği, 22(2), 169-186.

Yılmaz, A. (2009). Public policies and public library-emergent literacy relationship in the USA. Bilgi Dünyası, $10(1), 80-94$.

\section{Copyrights}

Copyright for this article is retained by the author, with first publication rights granted to the journal.

This is an open-access article distributed under the terms and conditions of the Creative Commons Attribution license (http://creativecommons.org/licenses/by/4.0/). 